\title{
Forum on the Nuffield Report The Forensic Use of Bioinformation: Ethical Issues
}

The UK has the largest forensic DNA database in the world, representing 6 percent of the population. It is a valuable tool for catching and convicting offenders: DNA evidence increases crime detection rates from 26 to 40 percent. Yet the establishment of the National DNA Database and the subsequent extensions to police powers were effected without any meaningful public debate. It was for this reason that the Nuffield Council on Bioethics, an independent body, decided that a critical examination of the subject was needed. It published a report The forensic use of bioinformation: Ethical issues in September 2007.

DNA can currently be taken, without consent, from any person arrested for a 'recordable' offence (mostly offences that can lead to a prison sentence). Since 2003, the police in England and Wales have been able to permanently store this DNA on the National DNA Database, even if the individual is never charged or is later found to be innocent. Indeed, up to 25 percent of the profiles on the database are from people who have never been convicted of any offence.

Despite police claims about the utility of the expanded database, the Nuffield Council found little evidence that keeping the DNA of people not charged or convicted increased crime detection rates. Home Office figures state that the DNA of 6,000 'innocent' people, retained on the Database since 2003, has been matched to crime scene samples. However, the Council notes in its report that it is not known how many of these matches led to convictions and, while the Database has almost doubled in size since 2003, detection rates involving DNA have not increased overall. It seems that the people now going onto the Database are too often not the ones committing crimes. The marginal benefit to crime detection does not justify the loss of privacy of many thousands of innocent people. Given this, the Council recommends that the police should only be allowed to keep the DNA of people who are convicted of a crime, with the exception of people charged with serious, violent or sexual offences.

The Council also made a number of other recommendations relating to storing the DNA of witnesses, victims, volunteers and children, and the expanding uses of the DNA Database, for example, for research and inferring the ethnicity of potential suspects.

In this Forum we continue the examination of forensic DNA databases by asking a small group of academics and practitioners from European countries other than the UK to provide brief commentaries on the Nuffield Report. Complementing this DNA database discussion is a more in-depth commentary by Simon Cole focused on fingerprinting-the second of the two biometric applications discussed in the Nuffield Report.

The Nuffield Report is available at www.nuffieldbioethics.org 